\title{
Adenosine -Induced Flow Arrest and Microsurgerical Clipping in Difficult Cerebral Aneurysm Surgeries
}

\author{
Mannará Francisco Alberto ${ }^{1,2 *}$, Alonso Soledad ${ }^{1}$, Gonza Hernán ${ }^{1}$, Fernández Javier ${ }^{1}$, Stupka Sara ${ }^{3}$, Civilotti \\ Roman $^{3}$ and Gardella Javier ${ }^{1,2}$ \\ ${ }^{1}$ Department of Neurological Surgery, Hospital of High Complexity Juan D Perón, Argentina \\ ${ }^{2}$ Department of Neurological Surgery, Hospital Fernández, Argentina \\ ${ }^{3}$ Department of Anaesthesic, Hospital of High Complexity Juan D Perón, Argentina
}

Submission: October 24, 2016; Published: December 01, 2016

*Corresponding author: Mannará Francisco Alberto, Avalos 1536, (1431), Buenos Aires, Argentina, Tel: 5491154996753;

Email: fmannara@hotmail.com

\begin{abstract}
Transient flow arrest caused by induced Adenonsine administration has been used to facilitate microsurgical clipping in some cases of cerebral aneurysms. Here, we described our experience in two cases where adenosine induced flow arrest facilitate to place the clip in the neck of aneurysm without any complication, in cases where proximal control is not possible.
\end{abstract}

Keywords: Adenosine; Flow arrest; Cerebral aneurysm; Aneurysm clipping

\section{Introduction}

Endovascular techniques in the treatment of cerebral aneurysms had evolved advances in the field, however, microsurgery with clip occlusion of the aneurysm's neck is still a mainstay in definitive treatment. Intraoperative rupture of the cerebral aneurysm can have undesired consequences. To avoid rupture, proximal temporary arterial occlusion is used to decrease the turgor of the aneurysm neck, thereby facilitating clip occlusion of the aneurysm or clip reconstruction of the carotid artery. Sometimes, it is difficult to find an anatomically suitable place for temporary arterial occlusion for carotid paraclinoid aneurysms or giant aneurysms, even with clinoidectomy performed. In such cases, the use of adenosine can facilitate surgery, producing reversible flow-arrest. This helps in decompressing the aneurysm sac and improve visualisation to facilitate clip application. We present two cases where the use of induced adenosine flow arrest facilitate to place the clip in the prompt positition without any complication.

\section{Case Presentations}

\section{Case 1}

51 years old female patient, antecedent of endovascular coiled left paraclinoid aneurysm 2 years before, with posterior amaurosis. She was admitted at hospital with a ruptured carotid ophthalmic on the right side (Figure 1). She was scheduled for surgical clipping of the aneurysm. In anticipation of intraoperative rupture, we planned administration of intravenous adenosine. The patient was placed with external defibrillator paddles in position. We performed a right frontotemporal craniotomy with intradural clinoidectomy. When we exposed the neck, we confirmed a great tension on wall of the artery, with the optic nerve displaced uprighted, so it was difficult to clip the aneurysm with safety (Figure 2). We administered 18 $\mathrm{mg}(0.3 \mathrm{mg} / \mathrm{kg})$ adenosine via central venous catheter in a quick bolus with $20 \mathrm{ml}$ of normal saline flush, which resulted in flow-arrest and transient asystole lasting for 20 seconds .This facilitated further dissection, softing the walls of the dome and neck, (Figure 3) and application of permanent clip . Exclusion of aneurysm was confirmed with Doppler ultrasonographic device. (20 MHZ Mizuho Doppler). Sinus recovery occurred after about $20 \mathrm{~s}$ and normal sinus rhythm was recovered. The patient did not suffer any cardiological or neurological consecuence. We repeated electrocardiograms (ECGs), echocardiograms and Troponin I assay post-operatively at 6 and $24 \mathrm{~h}$, respectively, which were within normal limits. 


\section{Open Access Journal of Neurology \& Neurosurgery}
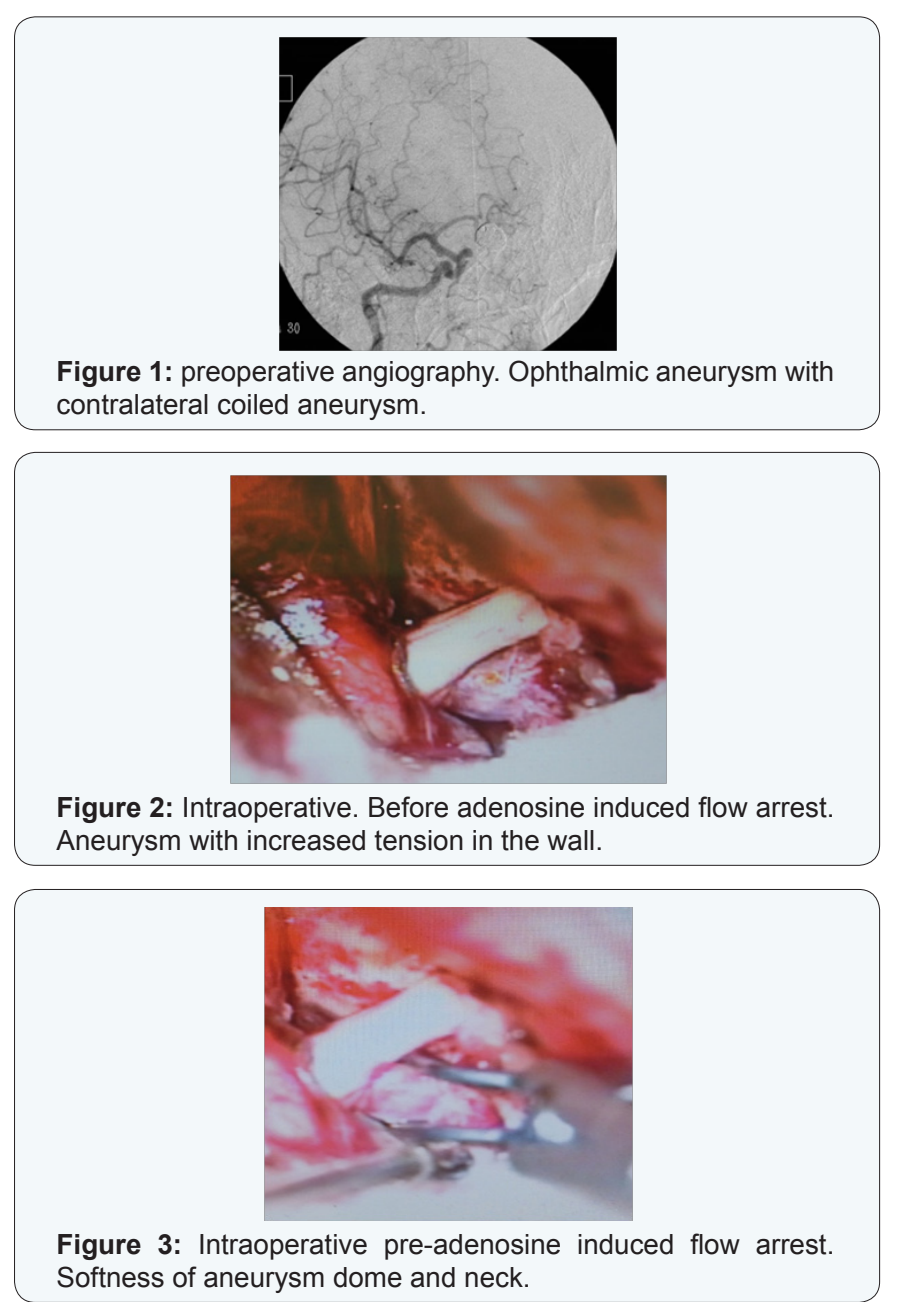

\section{Case 2}

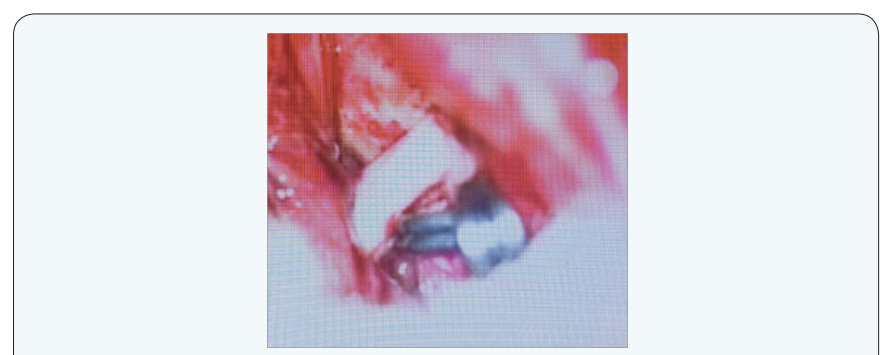

Figure 4: Intraoperative photograph showing the clipped aneurysm.

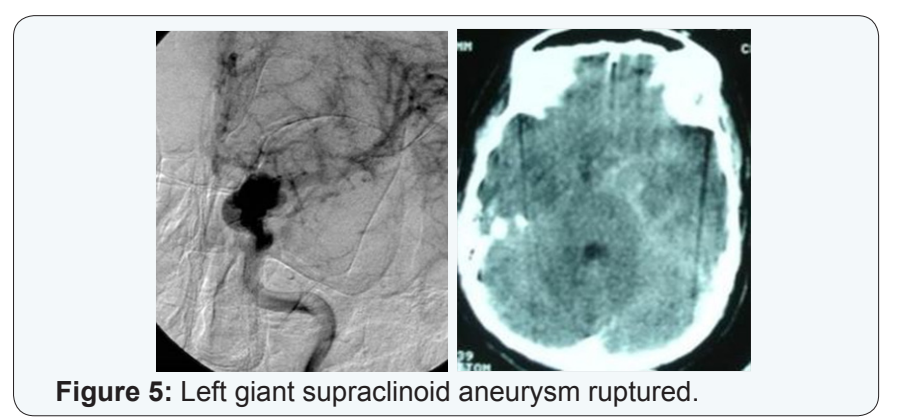

35 years old patient with subarachnoid haemorraghe, Hunt and Hess grade IV, Fisher 4, with left giant supraclinoid carotid aneurysm (Figure 4, Figure 5). We planned treatment by clip reconstruction and anticipated the use of adenosine to facilitate dissection and deal with a possible intra-operative rupture. During dissection, the aneurysm ruptured.

Adenosine $18 \mathrm{mg}$ IV was administered as a quick bolus through the central line with $20 \mathrm{ml}$ of normal saline flush. Asystole was achieved for 25 seconds, during which, we could reconstructed with fenestrated multiclipping technique the parent artery, with exclusion of aneurysm. With Mizuho Doppler we confirmed patency of internal carotid artery. Following asystole, the patient heart rate recovered spontaneously without any haemodynamic sequelae.

\section{Discussion}

Adenosine is an endogenously occurring nucleoside analogue, which reduces heart rate and prolongs conduction through the sinoatrial and atrioventricular nodes, acting on cardiac A1 receptor to decrease cyclic adenosine monophosphate. It has an ultra-short half-life $<10 \mathrm{~s}$, secondary to reuptake by red blood cells and vascular endothelial cells [1].

Due the very short negative dromotropic and chronotropic effect on cardiac sinoatrial and atrioventricular nodes, Adenosine is usually indicated in paroxysmal supraventricular tachyarrhythmia. The administration of adenosine in patients with normal sinus rhythm induces a rapidly reversible cardiac arrest. The intravascular half-life of adenosine at the physiologic level is less than a second [1-3].

Adenosine-induced flow arrest offers a unique method to reduce cerebral perfusion pressure briefly and controllably and can facilitate the clip ligation of many aneurysms that were previously treated with deep hypothermic circulatory arrest, temporary occlusion of the extracranial carotid artery, or endovascular balloon catheter retrograde suction deflation $[4,5]$.

In the case number 1 we used adenosine because the great tension on the wall of the aneurysm. Sometimes, we had opened the aneurism and, deflate it to perform the clipping, but this option we used it when the wall is calcified or with thrombosis. The patient was young, and didn't have calcified wall, so adenosine induced flow arrest facilitate the clipping, softing the walls without the need to retract optic nerve.

In a case of an aneurysm rupture, adenosine has been used successfully to induce transient cardiac arrest to stop the bleeding when suction fails to clear the operative field, allowing the surgeon to place temporary or permanent clip under visual control [6-10].

In our experience, when we deal with an intraoperative aneurysm rupture, we try to gain proximal control, and transient 


\section{Open Access Journal of Neurology \& Neurosurgery}

clip is used. Furthermore, lowering systolic pression facilitate to face this situation. In such circumstances, maybe we don't need to use adenosine. In the case number 2, we didn't have proximal control to manage the bleeding. In such circumstance, adenosineinduced flow arrest was useful to clip aneurysm. However, the surgeon should think in this possibility to prepare the patient prior to perform the surgery, considering the placement of external defibrillator pads on all patients who might receive adenosine, to provide external pacing capability if prolonged asystole/ bradycardia were to develop, or cardioversion in the face of hemodynamically unstable atrial fibrillation. In addition, monitoring all these patients for biochemical evidence of myocardial injury (e.g., troponin I) in the postoperative period has now become our standard practice to perform appropriate subsequent evaluation for those with a positive response.

\section{Conclusion}

The use of adenosine- induced flow arrest, in cerebral aneurysms in which temporary occlusion is impractical or difficult, provides a safe option to facilitate microsurgical clipping.

\section{References}

1. Belardinelli L, Linden J, Berne RM (1989) The cardiac effects of adenosine. Prog Cardiovasc Dis 32: 73-97.

2. Möser GH, Schrader J, Deussan A (1989) Turnover of adenosine in plasma of human and dog blood. Am J Physiol 256 (4 Pt 1): 799-806.
3. Pelleg A, Belardinelli L (1999) Cardiac electrophysiology and pharmacology of adenosine: basic and clinical aspects. Cardiovasc Res 27: 54-61.

4. Parkinson RJ, Bendok BR, Getch CC, Yashar P, Shaibani A, et al. (2006) Retrograde suction decompression of giant paraclinoid aneurysms using a No. 7 French balloon-containing guide catheter. Technical note. J Neurosurg 105(3): 479-481.

5. Bebawy J, Gupta D, Bendok B, Hemmer L, Zeeni C, et al. (2010) Adenosine-Induced Flow Arrest to Facilitate Intracranial Aneurysm Clip Ligation: Dose-Response Data and Safety Profile. Anesth Analg 110(5): 1406-1411.

6. Groff M, Adams D, Kahn R, Kumbar UM, Yang BY, et al. (1999) Adenosine-induced transient asystole for management of a basilar artery aneurysm. J Neurosurg 91(14): 687-690.

7. Heppner P, Ellegala D, Robertson N (2006) Basilar tip aneurysmadenosine induced asystole for the treatment of a basilar tip aneurysm following failure of temporary clipping. Acta Neurochir 149(5): 517521.

8. Nussbaum E, Sebring L, Ostanny I, Nelson WB (2000) Transient cardiac standstill induced by adenosine in the management of intraoperative aneurysmal rupture: technical case report. Neurosurgery 47(1): 240243.

9. LuostarinenT, Takala R, Niemi T, Katila A, Niemelä M, et al. (2010) Adenosine-induced cardiac arrest during intraoperative cerebral aneurysm rupture. World Neurosurg 73[2]: 79-83.

10. Guinn N, McDonagh D, Borel C, Wright D, Zomorodi A, et al. (2011) Adenosine-induced Transient Asystole for Intracranial Aneurysm Surgery: A Retrospective Review. J Neurosurg Anesthesiol 23(1): 3540.

Your next submission with JuniperPublishers
will reach you the below assets
- Quality Editorial service
- Swift Peer Review
- Reprints availability
- E-prints Service
- Manuscript Podcast for convenient understanding
- Global attainment for your research
- Manuscript accessibility in different formats
( Pdf, E-pub, Full Text, audio)
- Unceasing customer service
Track the below URL for one-step submission
http://juniperpublishers.com/online-submission.php

